\title{
St. Marie-handelspladsen i Flensborg
}

\author{
af HANS-FRIEDRICH SCHÜTT
}

Den tidligere mangeårige leder af byarkivet i Flensborg, Dr. Hans-Friedrich Schütt, har gennem mange år arbejdet med byens ældste historie. Her fremlægger han nye resultater og teser om tilblivelsen af den bydel, som ligger rundt om byens Nørretorv og St. Marie kirke. Grundlæggelsen og befæstningen kan være et udtryk for den danske kong Valdemar den Stores virksomhed.

\section{Indledning}

Anlæggelsen af handelspladsen omkring Nørretorv og St. Marie kirke i Flensborg er en del af historien om Flensborg bys opståen. St. Mariehandelspladsen voksede frem formentlig fra 1000-årene, og dens udvikling som en selvstændig enhed varede indtil midt i 1200-årene. I flere hundrede år har historikerne arbejdet med at nå til klarhed om byens tilblivelse. ${ }^{1}$ Udforskningen af Flensborgs opståen er meget vanskelig, da der knap findes skriftlige kilder og kun meget få arkæologiske.

Ikke desto mindre er det $\mathrm{i}$ de sidste 100 år lykkedes at øge vor viden om byens allerførste tid væsentligt. Det fremgår klart af Erich Hoffmanns artikel fra 1984 "Die Entstehung Flensburgs«; han giver et eksakt overblik over den foreliggende viden om emnet. ${ }^{2}$ I betragtning af den vanskelige kildesituation er det imidlertid næppe muligt at nå frem til entydige resultater - en god del arbejdshypoteser og analogislutninger er nødvendige og kan ikke undgås. Men nye fund betyder, at forlængst kendte kilder må tydes og analyseres på en ny og anderledes måde. Det er også tilfældet når det gælder den handelsplads, som opstod ved St. Marie kirke i Flensborg. De byarkæologiske gravninger, som blev udført af Landesamt für Vor- und Frühgeschichte i 1988 og 1989, ${ }^{3}$ og erkendelsen af overensstemmelser mellem Flensborgs ældste kendte bysegl og de arkæologiske gravningsresultater fra Søborg på Sjælland, ${ }^{4}$ gør det nødvendigt at revidere den hidtidige viden - og fører til nye resultater. 


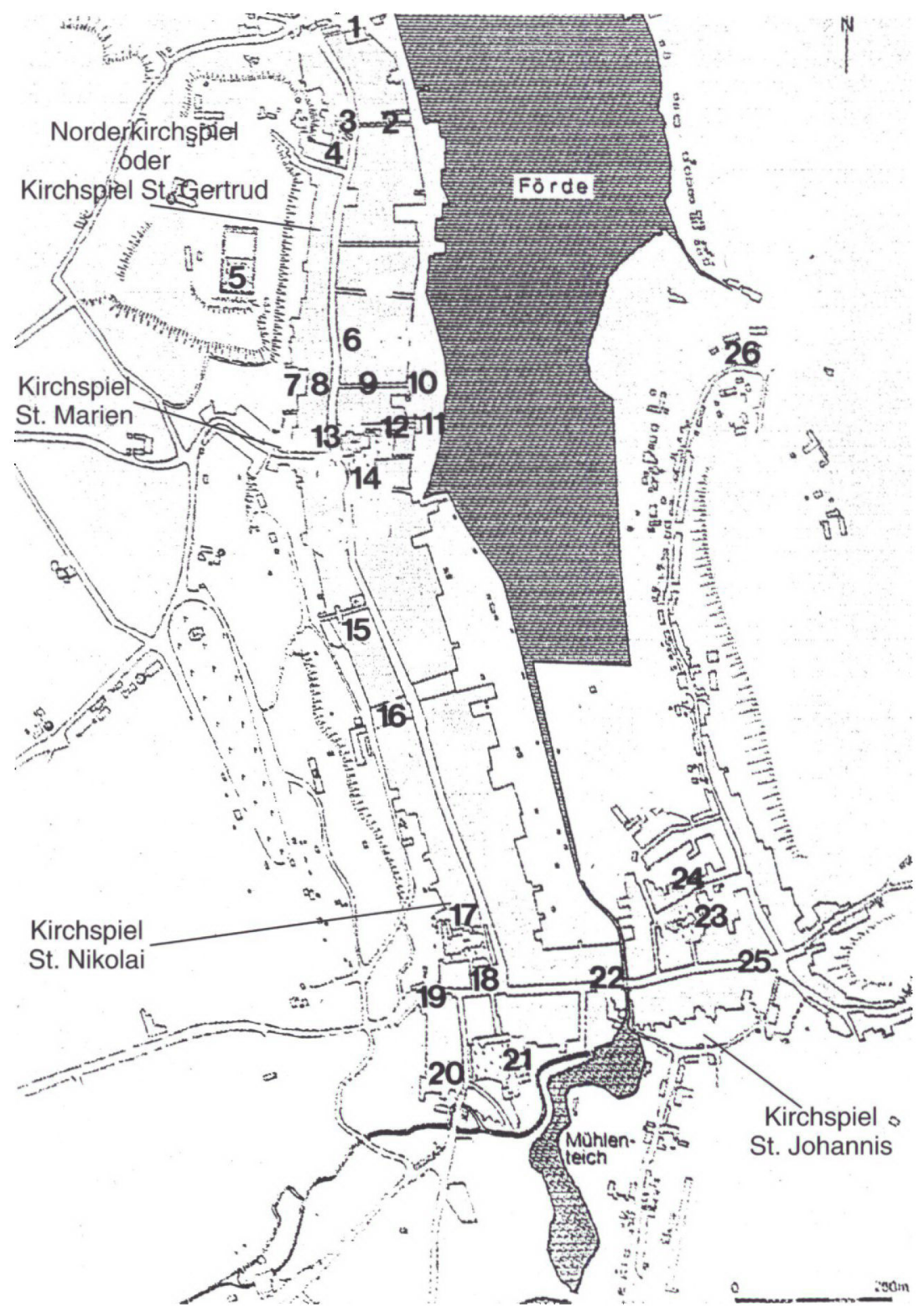

På dette 1800-tals bykort over Flensborg er indtegnet den middelalderlige bys opdeling $i$ bydele/kirkesogne.

Kort gengivet efter Flensburger Bilderbögen 3, Flensburg in der Zeit der Waldemare, 1992 Abb. 2. 
Før oprettelsen af handelspladsen ved St. Marie fandtes der så vidt vi kan se to små bopladser i området, nemlig ved St. Hans kirke ved fjordens sydøstende og omkring den forsvundne St. Gertrud kirke, dér hvor de nuværende gader Norderfischerstraße og Schloßstraße skærer Norderstraße. Disse to tidlige bosættelser har sikkert været sæsonmarkeder, "købinge«, med en meget beskeden befolkning af landsbykarakter. Senere, efter St. Marie bebyggelsen, kom omkring 1240 handelspladsen omkring Søndertorv/Südermarkt, som blev anlagt af hertug Abel. Det er den senere St. Nikolai-bebyggelse. Grundlæggelsen af de to markedsbebyggelser ved St. Marie og St. Nikolai er $\mathrm{i}$ grunden to forskellige bygrundlæggelser umiddelbart ved siden af hinanden. Her skal opmærksomheden samles om bopladsen ved St. Marie. ${ }^{5}$

Om bygrundlæggelser i højmiddelalderen er der skrevet meget. Byhistorien for denne tid har udviklet sig til en hel disciplin for sig. I sammenhængen her er det dog tilstrækkeligt at betragte tre strukturelementer, som havde betydning ved alle bygrundlæggelser: kirken, landsherren og borgernes organisation eller samfund.

\section{Bygrundlæggelsens tre komponenter}

Kirken

Når der blev anlagt en handels- og havneby var det mest vanskelige, men også det mest påtrængende problem at skabe et område, hvor der var sikret »fred « - i dag ville vi sige »retssikkerhed « - en fred, som gjorde det muligt for skippere, købmænd og håndværkere at

Dette refererer til kortet på foregående side.

1. Norreport.

2. Norderfischerstr./Norrefiskergade.

3. St. Gertruds-kapellet.

4. Schlossstrasse/Slotsgade.

5. Duborg.

6. Knudsgildegairden.

7. Vandmollen.

8. Neues Tor/Nyport.

9. Neue Strasse/Nygade.

10. Tårnborgen.

11. Kompagniporten.

12. Kompagniestrasse.

13. St. Marie-Kirke.

14. Norretorv.
15. Helligåndshospitalet, senere den danske kirke.

16. Tingpladsen, senere rådhus.

17. St. Nicolai-kirke.

18. Sïdermarkt/Søndertorv.

19. Friesisches Tor/Friserporten.

20. Rotes Tor/Rode Port.

21. Franciskanerklostret.

22. Mühlentor/Malleporten.

23. St. Johannes kirke/St. Hans kirke.

24. Damhof.

25. Angelburger Tor/Angelboporten.

26. St. Jorgens hospitalet. 
handle og arbejde $\mathrm{i}$ ro. Almen retssikkerhed fandtes ikke dengang. Retten var knyttet til personer, som kunne søge deres "ret« ved det ting, hvortil de hørte. Det var dog ikke til nytte for søfolk og købmænd, som dengang nok havde fast bopæl, men kun var hjemme om vinteren og ellers rejste rundt med deres varer, så meget mere som grænserne mellem røveri og køb var flydende både til lands og til vands. De havde brug for et sted, hvor der rådede en permanent, højere fred som var anerkendt af alle. Kun kirken kunne yde en sådan fred, så at sige en »hellig fred « inden for et kirkeligt område. Derfor hørte bygning af en kirke med kirkegård og anlæggelse af et marked sammen, ligesom også den umiddelbare adgang til markedet fra skibbroen og byportene.

Det var ikke blot sådan, at budet om kristelig fred, forpligtende for alle kristne, skabte en forøget retssikkerhed inden for den nye handelsplads. Den kirkelige ret, den såkaldte "kanoniske ret ", greb også grundlæggende ind $i$ handels- og omsætningsretten, f.eks. ved sit forbud mod udlån mod rente, ${ }^{6}$ mod pantsæetning ${ }^{7}$ og andre bestemmelser.

Markedsfreden forudsatte derfor samtidig et opsyn med markedet. Gennemførelsen af den kirkelige fred og markedsopsynet i den nygrundlagte by var kongens eller hertugens opgave.

I frrste fase af enhver bygrundlæggelse stod således anlæggelse af en kirke og en markedsplads. Flensborgs nuværende St. Marie kirke blev som det fremgår af et bevaret dokument indrettet "på ny « omkring 1284. ${ }^{8}$ Den havde altså en forgænger, hvoraf der endnu findes rester i den nuværende kirke. Denne tidliggotiske forgængerbygning kan næppe være opstået før 1230. Det er muligt, at den er bygget på den tid, da kongesønnen Abel førte titlen hertug af Slesvig (fra 1231) eller også udførte denne funktion (fra 1237). I så fald kan kirken allerede være ødelagt i broderkrigen mellem kong Erik og hertug Abel (1248). Måske skete det først 1261, i krigen mellem kong Erik Klipping og de holstenske grever. ${ }^{9}$ Spor af en romansk forgængerbygning, evt. i stil med den kirke af granitkvadre, som gik forud for Haderslev Vor Frue Kirke, er ikke bevaret. En så kostbar bygning ville næppe heller være at vente i Flensborg. Haderslevs og Flensborgs økonomiske placering var dengang forskellige. Haderslev var en østkysthavn svarende til Ribe, som næst efter Slesvig var en af de to virkelig betydningsfulde handelscentre i vort område. Den betydning som »Viti og Modesti dag«, dagen hvor kongen vandt Rygen, længe havde for 
Haderslev, ${ }^{10}$ antyder vel at der allerede i 1100 -årene foregik handel over Ribe-Haderslev og ind i Østersøen, og at denne handel blev truet af faren fra venderne, så kong Valdemar 1. den Stores sejr over venderne i 1169 betød en afgørende vending til det bedre. Derimod har gravninger på Flensborgs Nørretorv ikke bragt fund, som viser en handelsmæssig betydning for torvet allerede i 1100-årene. ${ }^{11}$ Udgravningsresultaterne tyder på et nyanlæg i slutningen af 1100-årene eller først i 1200-årene. Marie-kirkens beskytterrolle (patrocinium) peger på en kirkegrundlæggelse i det sene 1100 -tal, ${ }^{12}$ og ved nyanlæggelse af en handelsplads må man i alle tilfælde i vort område regne med at der er begyndt med en kirkebygning af træ. ${ }^{13}$ Når det gælder handelspladsens kirkelige tilknytning kan man således på indeværende tidspunkt blot antage, at begyndelsen har ligget før 1230, måske endda lidt før 1200.

\section{Landsherren}

I den tidlige middelalder og højmiddelalderen rådede der vel ikke et "sakralkongedømme", hvor kongen i sin person forenede den øverste verdslige og præstelige funktion, men kongedømmet havde dog et sakralt fundament. Oprindelig, i hedensk tid, opfattede kongefamilierne sig som efterkommere af guderne. Da kristendommen havde sejret, gjaldt den valgte konge som kaldet af Gud, og derfor omfattede hans embede såvel det verdslige som det kirkelige. Kaldelsen fra Gud blev understreget, da Valdemar 1. den Stores far Knud Lavard 1170 blev ophøjet til helgen, og kongeembedet derved så at sige fik en formidlerrolle mellem det jordiske og det himmelske. ${ }^{14}$

Ganske vist kunne kongen ikke gribe ind $\mathrm{i}$ den bestående retsordning og ændre retspraksis efter sin vilje, for også retten havde sakralt udspring og kunne ikke skabes eller forkyndes, men skulle blot fremfindes. Men kongen kunne oprette fredhellige områder, hvor der gjaldt en forøget fred i Guds og hans helgeners ånd. Sådan var det ved de klostre og det klostergods, som kongerne og kongefamilien indstiftede, og over hvilke de frem til kong Valdemar 1. den Stores tid kunne råde selvstændigt som familiens såkaldte »egenkirkelige« centre, navnlig hvad angår gravlæggelse. ${ }^{15}$

Sådan må det også antages at kongens vilje var normgivende ved de nygrundlagte byer indtil omkring år 1200 hvad angår det kirkelige midtpunkt $i$ den nye bebyggelse, f.eks. at han forbeholdt sig afgørel- 
sen ved indsættelsen af gejstlige. Indføringen $i$ embedet og indvielsen var derefter biskoppens sag. Indretningen af en ny by under kongens beskyttelse mindede således $i$ et "folkeretligt « præget område som vort om etablering af et »immunitetsområde«.

Helt generelt var det kongens opgave at tage vare på handelspladsens særlige fred. Han skulle beskytte byen mod angreb udefra, hvad enten den blev truet af fjender, røverbander eller naboer, og han skulle tage vare på retsfreden i byen selv. Begge dele var ikke muligt uden kongelige styrker. Derfor indsatte kongen $\mathrm{i}$ byen en byfoged ("advocatus«), som sammen med en skare af bevæbnede folk handlede på kongens vegne.

Til en bygrundlæggelse hørte følgelig en kongelig borg, som fast punkt ved byens forsvar i tilfælde af overfald eller belejring, eller som støttepunkt eller som et sted uden for byens jurisdiktion, hvor man kunne søge asyl ved indre uro i byen. En borg kunne også benyttes som fængsel med henblik på afstraffelse for brud på byfreden. Byfogeden med hans folk og kongeborgen forudsætter hinanden.

En sådan kongelig borg var der også ved St. Mariebyen i Flensborg, sådan som det ses afbildet på det ældste bysegl. I Flensborgs byhistoriske forskning har man hidtil antaget, at det tårn, som ses på Flensborgs bysegl, ${ }^{16}$ viser en Flensborg-landsherres tårnborg (dansk "barfred «). Man mente, at denne tårnborg måtte have været af træ, ${ }^{17}$ svarende til Flensborgs beskedne begyndelse. ${ }^{18}$ En nøje betragtning af det ældste bevarede segl fra $1350^{19}$ viser at denne antagelse er tvivlsom; facaden peger snarere i retning af store regelmæssigt behuggede kvadersten.

Egenartet er tårnborgens ottekantede form, egentlig kender man kun runde eller firkantet anlagte tårnborge ${ }^{20}$ Den nærliggende antagelse, at den ottekantede form er udtryk for seglstikkerens smag, kan imidlertid afvises. Ved udgravninger fra 1913 til 1947 af den vigtige middelalderborg i den senere forsvundne by Søborg i Nordsjælland fandt arkæologen C. M. Smidt fundamentet til en ottekantet tårnborg. Hans for så vidt meget omhyggelige undersøgelser ${ }^{21}$ blev dengang betvivlet af forskningen, navnlig af V. la Cour. Men i 1983 blev der foretaget en fornyet udgravning, 22 som ikke blot bekræftede Smidts resultater, men også kunne datere tårnborgen til årene umiddelbart efter 1160, altså til kong Valdemar 1. den Stores første regeringsår, da kampen mod venderne var bestemmende for kongens politik.

Udgravningerne viste også, hvordan tårnborgens ottekantede form 

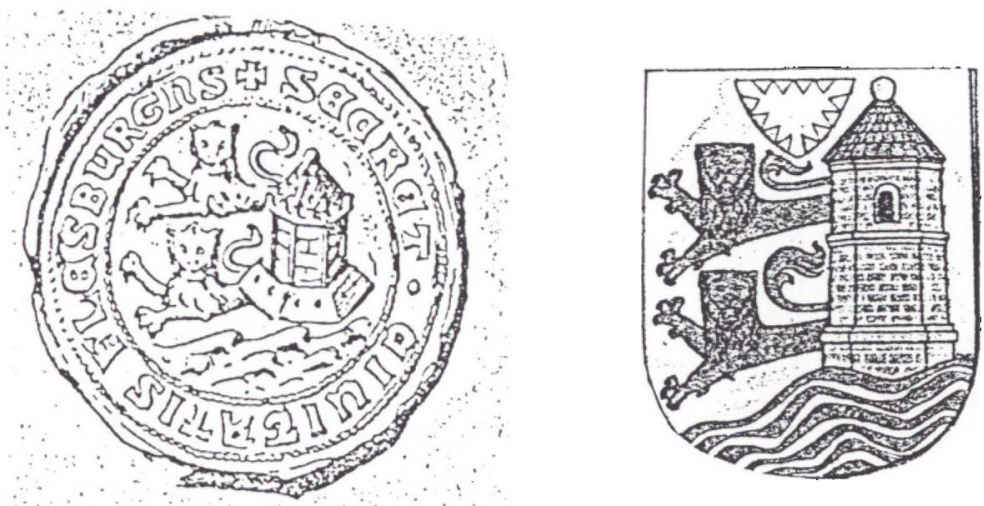

Flensborgs bysegl omkring 1350 og tegning af byvåbnet fra 1930'erne. Gengivet efter Erwin Nöbbe: Die älteren Siegel und das Stadtwappen von Flensburg, $i$ : Unser Schleswig, 1934 s. 31-34 samt Verwaltungsbericht der Stadt Flensburg 1936-1937, Flensborg 1938 s. $2 f$.

skulle forklares. Den skyldtes, at tårnborgen hvilede på et stjerneformet, ottekantet fundament af svære egebjælker, ${ }^{23}$ som bar lodret stående egebjælker og sammen dannede en art bindingsværkkonstruktion, ${ }^{24}$ som kan have støttet muren af kampesten og kalkmørtel, som sluttelig blev beklædt med behugne kvadersten. Den ottekantede tårnborg kan anses for en overgangsform mellem tårnborgen af træ og den af teglsten, som da nok blev benyttet af kong Valdemar allerede i 1160'erne.

En sådan tårnborg har der også været i Flensborg, og den er ikke kun kendt fra seglet. Hvis man antager, at den er blevet moderniseret i forbindelse med den kostbare opbygning af Duborg Slot (efter 1410) og befæstelsen af bydelen Ramsherred (Norderstraße) nedenfor Duborg, er den identisk med det bytårn, som indtil 1700-årene lå i skæringspunktet mellem de nuværende gader Neue Straße/Schiffbrücke, og som var sæde for Flensborg-byfogeden. Denne tårnborg med dens gammeldags-tunge stenkvadre ses på gamle byprospekter. Den blev først nedrevet 1771. En del af granitkvaderstenene blev genanvendt $i$ skalmuren på Adelby kirkes tårn. ${ }^{25}$

Til landsherrens tårnborg hørte der en ydre befæstning, som måske antydes på seglet fra 1350 i ottekantet form. Som Søborg lå også Flens(å)borg direkte ved vandet. Beskyttelse fik den måske desuden af bækken, som bruste ned til havnen gennem dalen ved de nuværende gader Marienstraße/Toosbüystraße. ${ }^{26}$ 
ret præcis datering af anlæggelsen af handelspladsen ved Marie kirken med Nørretorv. For det andet er det bemærkelsesværdigt, at den kongelige tårnborg blev indrettet meget kostbart og solidt. Den kunne da også modstå hansetroppernes stormangreb 1431, omend på daværende tidspunkt renoveret og ombygget. Tårnet blev heller ikke nedrevet i 1771, fordi det var brøstfældigt, men fordi det ikke længere var tidssvarende som fængsel. ${ }^{28}$

\section{Bysamfundet ${ }^{29}$}

Det vigtigste ved grundlæggelsen af en by var bosættelsen af befolkningen. Men der må skelnes mellem indbyggere og borgerskab. Indbyggere var alle, som havde fast bopæl i byen. Borgerskabet bestod af indbyggere, som også var hus- og grundejere. Kun borgere var dengang tingberettigede, d.v.s. de dannede »bythinget", som sørgede for retsplejen og afvikling af de almindelige byting. Borgerne repræsenterede som "husherrer" $\mathrm{i}$ ordets egentlige betydning deres familie og ansatte for retten. Det gialdt også for handelsvenner eller handelspartnere, der som "gæster" boede hos dem. I og for sig var fremmede handlende og håndværkere retsløse. Da købmænd og handlende rejste rundt med deres varer, var de derfor anvist på det skiftende gæstevenskab, uden hvilket handel og vandel ikke kunne finde sted.

Ejere af hus og gård var borgerne dog ikke på det tidspunkt, da "Mariebyen « Flensborg blev anlagt. De blev bosat på grund og jord, som tilhørte kongen. Byens hovedfærdselsåre, ud til hvilken de enkelte gårde blev anlagt, forblev som "Haerscopstrate « landsherrens ejendom længe efter at borgerne var blevet ejere af deres grundstykker. For deres grundstykker betalte de nybosatte borgere i højmiddelalderen afgifter, som man oprindelig ikke kan betragte som skatter, men snarere som en slags forpagtningsafgift til kongen: den såkaldte »arnegæld" og "toftgæld «. Gæsterne betalte markedsgæld ("torchørtich (), en afgift som berettigede til at bruge markedet. For at kunne lade hus og gård gå i arv måtte borgerne erlægge "arvegæld«. Indkrævelsen af disse afgifter var en vigtig opgave for byfogeden. Kongens beskyttelse blev altså betalt både med en vis afhængighed og med afgifter. Denne borgernes afhængighed var rent formelt synlig endnu i 1700årene: De nye borgere aflagde fortsat deres borgered på den kongelige byfogeds sværd. 


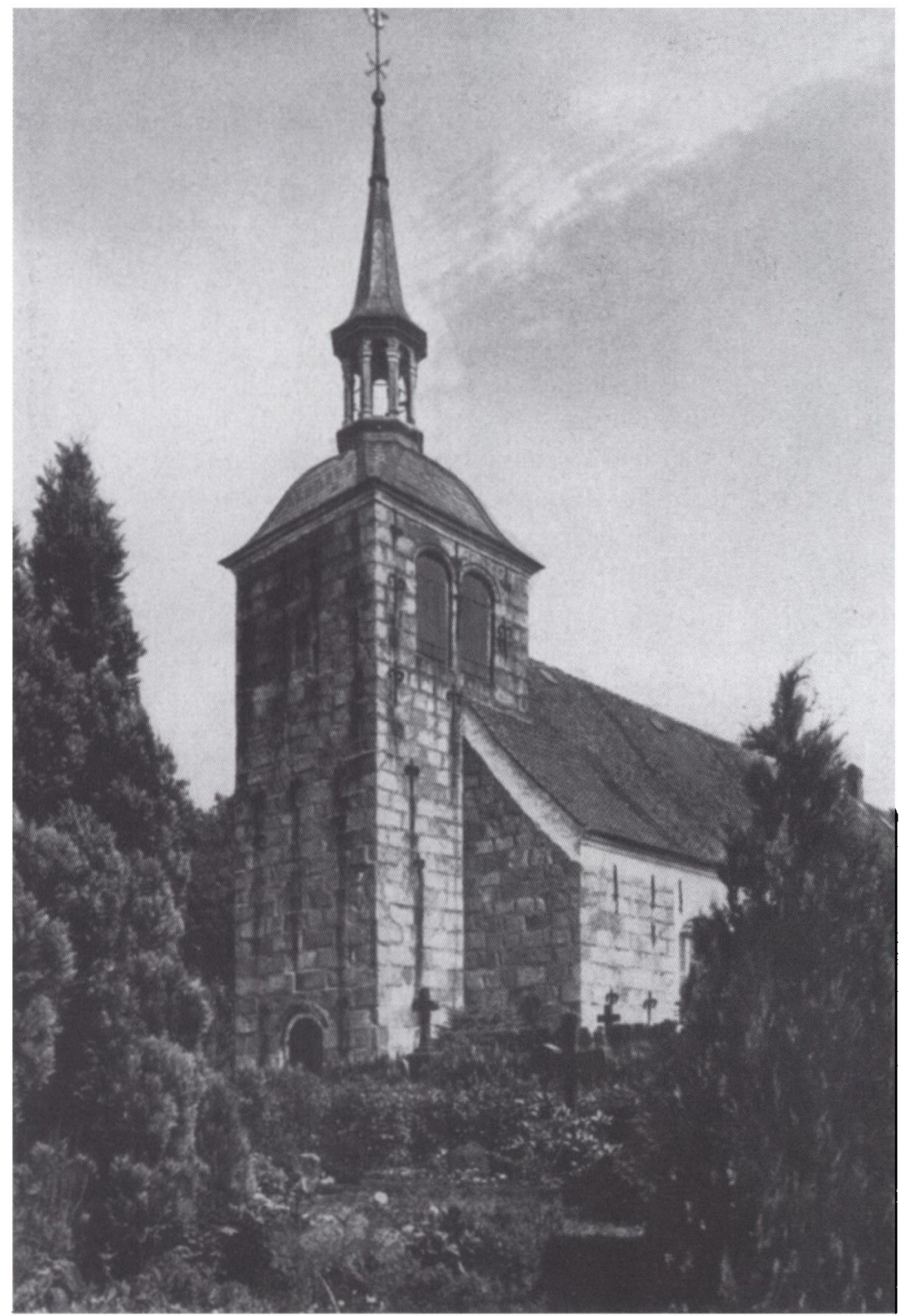

Adelby kirke set fra sydvest. Stentårnet blev bygget $i 1726$ og atter totalt renoveret $i$ årene 1774-1780. Til denne ombygning købte kirken fra Flensborg by en mængde granitkoadre, som efter alt at domme stammede fra tårnborgens nedbrydning. De blev benyttet til at skalmure tårnet, så det blev vejrbestandigt. Adelby kirkes tårn giver på den måde endnu i dag et indtryk af Flensborg-tårnborgens udseende. Dog er kirketårnet med dimensionen $4 \times 4 m$ kun knap halvt så bredt som »barfreden « $i$ Flensborg. Foto efter Die Kunstdenkmäler des Landkreises Flensburg (1952). 
I øvrigt regulerede borgerne formentlig i vid udstrækning selv byens anliggender. Der fandtes en slags styrende organ, som bestod af borgere, d.v.s. i reglen de borgere der var "meliores«, altså »mere værd« end de andre. Disse borgere var sluttet sammen $i$ et »overgilde« (»summum convivium«). Dette overgildes særlige karakter bestod, udover i den særlige velstand, som dets medlemmer havde erhvervet, deri, at de stod direkte i kongens tjeneste, på samme måde som »dem, der dagligt tjente ham «. ${ }^{30}$ De hørte altså på en vis måde retsligt til kongens tyende eller tjenestefolk. Deres virksomhed for kongen kan have bestået $i$, at de som led i deres handel afsatte de naturalafgifter, som kongen modtog og på den anden side besørgede og indkøbte de varer, som kongemagten havde brug for, og som ikke blev fremstillet $i$ landet selv. Den særlige stilling som kongetjener indebar en særlig retsstilling ikke kun i indlandet, men også på rejser. På den anden side betød det naturligvis også, at overgildets købmænd var bundet af kongens anvisninger.

Både i Flensborg og i Slesvig bar overgildet navnet St. Knudsgilde. Dette navn kan gildet $i$ alt fald have ført fra 1170, da Knud Lavard, kong Valdemar 1. den Stores fader, officielt blev erklæret for helgen. Men gildets forbindelse til Knud Lavard rækker langt tilbage, hans "offerdød " var allerede forinden blevet opfattet som noget helligt. Derfor kan man lade det stå åbent, om overgildet allerede før 1170 har æret ham som skytspatron. Overgildet var et meget fast forbund, et edsforbund, som levede efter faste regler. I Flensborg er det også tydeligt, at det var et styringsinstrument som, i nogen lighed med den samtidige landsbyforfatning, forberedte tingmøderne og deres beslutninger og påvirkede dem. Det fremgår særlig tydeligt ved bysamfundets oprindelige finansstyre og skal derfor nævnes som eksempel her: Bysamfundets udgifter blev lagt ud af de borgere, som rådede over tilstrækkelige frie midler. Pengegiverne har sikkert været de såkaldte "meliores «, som sad i overgildet. Ved årets afslutning blev der aflagt regnskab, der blev beregnet en »Umlage «1 (fordeling/udskrivning), som blev indkrævet, og pengegiverne fik deres udlæg er-

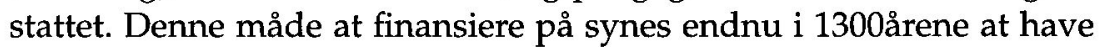
ligget i hænderne på St. Knudsgildet.

St. Knudsgildet havde som førende korporation i byen sit sikkert statelige domicil i Marie sogn, sandsynligvis indenfor det område, som i dag optages af grundstykkerne Nørregade 22 til 28. Det betyder, at de tre vigtigste komponenter $i$ den nygrundlagte by havde deres 
centrer tæt ved hinanden: mod syd Marie kirke med Nørretorv og gaden ned til skibbroen, Schiffbrückstraße, nord derfor omkring den nuværende Neue Straße landsherrens område med tårnborgen og vandmøllen, og sluttelig St. Knuds gildets gård som broderskabets område. Men de tre komponenter kan ikke adskilles, de er på mange måder kompliceret slynget ind $\mathrm{i}$ hinanden og udgør tilsammen et hele, som sammen danner det særegne $\mathrm{i}$ højmiddelalderens by her $\mathrm{i}$ vort land.

\section{Bygrundlæggelsen}

Vi ved ikke, hvordan Mariebyen blev grundlagt. Men man kan gå ud fra at kongen indsatte en »exactor« (opsynsmand, eksekutor, længere sydpå kaldt en »locator «), der på kongens vegne ledede grundlæggelsen af byen. ${ }^{32}$ Borgerne er med løfter, eventuelt under pres, som kongen jo kunne udøve, blevet foranlediget til at flytte til den nye bosættelse. En god del er vel kommet fra Slesvig, thi den senere stadsret fra 1284 var en variation af Slesvigs ret. I overgildet eller St. Knudsgildet rådede kongen over et sagkyndigt ledelsesorgan, som hans exactor kunne betjene sig af. Også her har kongen nok i første række betjent sig af gildebrødre fra Slesvig. De nødvendige "offentlige arbejder«, som man ville sige i dag, som anlæg af befæstning, skibbro og andet, blev udført af håndværkere, især tømrere, som kunne kaldes sammen til sådanne arbejder på kongens anvisning. Stenhuggere og murere hvervede kongen vel i regelen fra udlandet.

Den oprindeligt herskende antagelse, at St. Marie handelspladsen har begrænset sig til området umiddelbart omkring Nørretorv, er blevet revideret efter de nylige udgravningers resultater. Mod syd rakte den nye by mindst til husene Storegade 61 og 63,33 sandsynligvis indtil Helligåndskirken. Den daværende Store Gades bredde var kun omtrent det halve af den nuværende. Gaden svarede derfor i bredde til Kompagniestraße såvel som Schiffbrückstraße før 1870. Kirke, borg og Knudsgildegården har sikkert ikke ligget ved udkanten af den nye by, men snarere mere eller mindre $i$ centrum. Med Knudsgildets gildehus rækker den oprindelige Marieby ind i den nuværende Norderstraße. Også på dette punkt er der altså brug for nytænkning.

Byens todeling $i$ et St. Marie sogn og Ramsherred er sikkert først et resultat af de store befæstningsarbejder efter 1410. Den "nye port « og "Neue Straße« var i 1400 tallet faktisk nye og ændrede grundlæggen- 
de byens topografi. Den forste Marieby kendte ikke til dette indsnit og rakte længere mod nord. Hvor langt den rakte og om en ældre bosættelse - den $\mathrm{i}$ indledningen som påstand nævnte »købing « St. Gertrud - blev inddraget, det kan kun udgravninger afklare. Principielt må man også for så vidt tænke nyt, som Flensborg dengang ikke skal »tænkes« fra syd til nord, som det længe har været almindeligt, ${ }^{34}$ men fra nord til syd. På grundlag af de foreliggende indicier kan man kun formode, at Valdemar 1. den Stores bygrundlæggelse rakte fra den daværende Nørreport, kort nord for Norderfischerstraße og indtil Hellig-Geist-Gang, der hvor nu den danske Helligåndskirke ligger.

Inden for rammerne af denne hypotese ville det være betydningsfuldt, hvis den formodning kunne bekræftes, at Helligånds-hospitalet har haft en forgænger $i$ et St. Laurentius-Hospital, som kan have ligget mellem St. Gertrud-kirken og den nuværende Nørreport.

I hvert fald bliver det tydeligt, at St. Marie bygrundlæggelsen ingenlunde var så begrænset, som hidtil formodet. Den må snarere betegnes som af stort format og passer derfor til indretningen af en imponerende tårnborg omtrent $\mathrm{i}$ dens midte.

Kong Valdemar 1. den Stores hensigter ved anlæggelse af en sådan by Flensborg må have været begrundet i Slesvigs stagnation og Lübecks hurtige fremvækst. Sliens farvand og Slesvigs lavvandede havn var til afbræk for den gamle Slimetropols handelsmæssige betydning. For Slesvig var det også til skade, at Henrik Løve gav Lübeck en så massiv politisk støtte, hvadenten det var gennem traktater eller ved åbning af kysten langs Østersøens sydkyst. For hertug Henriks forbundsfælle og rival kong Valdemar 1. den Store gjaldt det om ikke at lade den så indbringende handel mellem Nord- og Østersøen glide sig af hænde til Lübeck. Vigtigt var det også, at den nordfrisiske handel ikke vandrede mod syd, men at der blev skabt en ny ydedygtig modhavn i det nyanlagte Flensborg, som jo let kunne nås fra de frisiske havne Læk og Tønder. Hvis Valdemar 1. den Store ville nå sådanne mål, så måtte hans planer have stort format.

Imidlertid skal man ikke undervurdere de vanskeligheder, som en sådan nygrundlæggelse stod overfor også under disse forhold. Det varede over 100 år, før Flensborg begyndte at blive en generende konkurrent for nabobyen Slesvig. En konkurrent til Lübeck blev Flensborg aldrig, i alt fald når man hvad angår det skandinaviske område ser bort fra tiden fra 1530 til 1610 . 
1. Om de lærde arbejder, som i 1600$1700 a ̊$ rene beskæftigede sig med byen Flensborgs opståen og som især samlede sig om at tyde navnet "Flensborg ", beretter Georg Claeden i 1. bind af $\sin$ "Monumenta Flensburgensia“, Flensburg 1768 s. 136f, 389 og 401.

2. Erich Hoffmann: Die Entstehung Flensburgs, i: Flensburg 700 Jahre Stadt, Schriften der Gesellschaft für Flensburger Stadtgeschichte nr. 36,1, Flensborg 1984 s. 23f, med litteraturhenvisninger.

3. Landesamt für Vor- und Frühgeschichtes byarkæologiske gravninger fandt sted 1988-89 og er endnu upublicerede. Lederen af disse gravninger, Dr. Willi Cramer, takkes for meddelelse om de vigtigste resultater, som har været relevante for nærværende artikel.

4. Hans-Friedrich Schütt: "Die als Steinbau errichtete Turmburg in Flensburg «, i: Offa 53, 1996.

5. Erich Hoffmann, 1984 s. 26f. St. Gertrud sogn inddrages kun i forngdent omfang.

6. Corpus Juris Canonici Kap. 52 II.

7. Corpus Juris Canonici Kap. 36 IV, 39 II.

8. "... ecclesiae beatae Mariae in Flensaeburch quandam ecclesiam lapideo opere de novo inceperant construendam ...«. Diplomatarium Flensborgense, udg. af H. C. P. Sejdelin, bd. 1, Kbh. 1865 nr. 6 s. $15 f$.

9. Iflg. Hans-Friedrich Schütt: Flensburg im Mittelalter, i: Flensburg, Geschichte einer Grenzstadt, SFSt nr. 17, Flensburg 1966 s. 23 og 27.

10. Hans-Friedrich Schütt: Zum Haderslebener Stadtrecht von 1292, i: Schriften der Heimatkundlichen Arbeitsgemeinschaft für Nordschleswig hft. $65 / 66,1992$ s. 5 . Det må antages, at den i byretten indskrevne festdag også derefter har haft en vis levetid.

11. Se note 3 .

12. Hans-Friedrich Schütt: Die dänischen St. Knudsgilden - mit besonderer Berücksichtigung der Gilden in Schles- wig und Flensburg, i: Gilden und Zünfte, Kaufmännische und gewerbliche Genossenschaften im frühen und hohen Mittelalter, udg. Berent Schwineköper, Vorträge und Forschungen, Sigmaringen 1985 s. 231ff, her s. $259 f$.

13. Arkæologiske undersøgelser i kirkens indre til klarlæggelse af spørgsmålet om forudgående bygninger er endnu ikke foretaget.

14. Erich Hoffmann: Die heiligen Könige bei den Angelsachsen und den skandinavischen Völkern - Königsheiliger und Königshaus, QuFGSH Bd 96, Neumünster 1975. Erich Hoffmann: Königserhebung und Thronfolgeordnung in Dänemark bis zum Ausgang des Mittelalters, Beiträge zur Geschichte und Quellenkunde des Mittelalters bd. 5 , Berlin 1976.

15. Thomas Hill: Könige, Fürsten und Klöster - Studien zu den dänischen Klostergründungen des 12 . Jahrhunderts, Kieler Werkstücke, R.A., Bd. 4, Frankfurt a.M. 1992.

16. Erwin Nöbbe: Die älteren Siegel und das Stadtwappen von Flensburg, i: Unser Schleswig, 1. årgang, $1934 \mathrm{~s}$. 31-34 og i Flensburger Nachrichten 25.1.1936.

17. I tilslutning til Erwin Nöbbe og Jakob Röschmann regner Fr. Frahm og A. Dammann i deres rekonstruktionstegninger af tårnborgen i Flensborg med en trækonstruktion. Grundlæggende er fortsat Jakob Röschmann: Vorgeschichte des Kreises Flensburg, Neumünster 1963 s. $93 \mathrm{f}$. Ham følger Vilhelm la Cour og Hans Stiesdal, i: Danske Borganlæg, bd. 1 og 2, Kbh. 1972 bd. 1 s. $79 f$ og 260.

18. I afsnittet om St. Marie-bygrundlægelsen taler Fritz Fuglsang i sin "Chronik der Stadt Flensburg" (1939), et arbejde som sammenfatter den tids opfattelse, om en "lille by ved Nørretorv « (s. 12).

19. Om segls udsagnskraft se H.F. Schütt: Die Turmburg in Flensburg (se note 4).

20. V. la Cour og H. Stiesdal: Danske Borganlæg, bd. 1 og 2, Kbh. 1972; Nils 
Knud Liebgott: Dansk Middelalder Arkæologi, Kbh. 1989; Rikke Agnete Olsen: Borge i Danmark, Herning 1986.

21. C. M. Smidt: Seborg. Fra Nationalmuseets Arbejdsmark 1930; samme i: Aarbøger for Nordisk Oldkyndighed 1934. samme: Søborg, i: Nordsjælland, Middelalderlige Mindesmærker, Hillerød 1939, også gengivet i Frederiksborg Amtshistoriske Samfunds Aarbog 1939 s. 26 f.

22. Robert Egevang og Søren Frandsen: Det ottekantede tårn, i: Nationalmuseets Arbejdsmark, Kbh. 1985 s. $73 f$.

23. C. M. Smidt (se note 21) og R. Egevang og S. Frandsen: Det ottekantede tårn (se note 22) er udforligt gengivet i H. F. Schütt: Die Turmburg in Flensburg (se note 4).

24. Denne tolkning går ud over Egevangs og Frandsens udgravningsberetning men kan muligvis understottes af seglbilledet fra Flensborg, sml. H. F. Schütt: Die Turmburg in Flensburg (se note 4).

25. Hertil og om tårnets skæbne i almindelighed se H.F. Schütt: Die Turmburg in Flensburg (se note 4).

26. At denne bæk oprindelig har båret navnet Flenså kan ikke udelukkes. Men alt i alt er forholdene meget uklare. Det synes som om bymarkens bække, også på bakkerne mod vest umiddelbart over byen, er blevet omledt gentagne gange.

27. Det er næppe sandsynligt, at den sagnomspundne benævnelse af byen efter ridderen Flens kan have haft en historisk kærne. Sådanne navne er normalt kombinationer skabt i de lærdes studerekamre. Et godt eksempel herpå er den almindelige opfattelse, at Duborg er benævnt efter ridderen Jens Due. Denne tydning går tilbage til en lærd sidst i 1800-tallet. Duborg er den folkelige benævnelse af borgen som (da.) Duerborg eller (middelnedertysk) Duvenborg=dueborg. Se om navnet Flensborg: Wolfgang Laur: Zum Namen Flensburg, ZSHG bd. 84,1960 s. 247f.

28. Om tårnets skæbne se H.F. Schütt: Die Turmburg in Flensborg (se note 4) med litteraturhenvisninger.
29. For dette afsnit er enkelthenvisninger overflødige. Borgerskabets retsstilling er fremstillet i Poul Johannes Jørgensen: Dansk Retshistorie, Kbh. 1971 (5. oplag) s. 418f. Om gildet se Hans-Friedrich Schütt: Gilde und Stadt, ZSHG Bd. 105, 1980 s. 77f.; samme: Die dänischen St. Knuds-gilden (se note 12). Forfatterens igangværende undersøgelser om overgilde, gilder og bysamfund er endnu ikke afsluttet.

30. Kong Knud 4.s stadfæstelse af Flensborg St. Knudsgildes skrå ca. 1200: "... wy taghem them allae under wort waern ogh wor fryth, sosum them thae ws dagligh thyene; ... Diplomatarium Flensborgense, udg. H. C. P. Sejdelin, Kbh. 1865 s. 7.

31. Denne "Umlage « blev fra 1300 tallet som byskat til en "Schate" eller "Schot", af hvilken en fast sum, den såkaldte "bede «, blev overført til landsherren. De gamle afgifter til landsherren forsvandt. Se H.F. Schütt: Flensburg im Mittelalter, i: Flensburg, Geschichte einer Grenzstadt, 1966 s. 53.

32. Det har været en person, som kunne anvende tvang, fremfor alt til at inddrive ydelser af enhver art, f.eks. afgifter og skatter. I vort område kendes ikke navn og samtidig betegnelse for den der havde bygrundlæggelsen i opdrag. Hans beføjelse svarede til byfogedens (advocatus). I Slesvigs og Flensborgs byretter betegner mexactor" og "advocatus" samme funktion, »exactor « er efter alt at dømme den ældste betegnelse. Ordet "Advocatus « betyder omtrent "den til retsvæsenet hidkaldte «.

33. Ved udgravningen dér $1988 / 89$ blev der fundet rester af bebyggelsen. Den dendrokronologiske datering peger efter alt at dømme på Valdemar 1.s tid.

34. Det drejer sig ikke kun om det aftagende sociale niveau fra Sendertorv nordpå, som har eksisteret $i$ århundreder, men om en i Flensborg indgroet, nærmest ubevidst grundfølelse, som betragter byen fra Sondertorv og nordpå. Det var sikkert anderledes $i$ Valdemarstiden. Det politiske, åndeli- 
ge og administrative centrum lå dengang mod nord. Også hvis man bringer byseglet $\mathrm{i}$ forbindelse med den

Oversættelse: Lars N. Henningsen her skildrede beliggenhed, så må man se bytårnet og rindende vand fra nord - kun da passer det. 